\title{
Brothers in Conflict: Reading the Prophet Obadiah Against the Context of the Political and Religious Hostility and Violence in Nigeria
}

\author{
Joel Kamsen TiHitshaK BiWUl (ECWA Theological Seminary, \\ Nigeria / STELLENBOSCH UNIVERSITY)
}

\begin{abstract}
This article discusses the resemblances between the text of the Prophet Obadiah and Nigeria within the political, economic, ethnic, and religious contexts of conflict and hostility of the latter. It puts forward the divine scandal, parental attitude of favouritism, and the careless disposition as well as the manipulative role of the Israelite and Edomites' progenitors as the foundational root factors for the expression of generational hostility presented in this prophetic book. In contrast, the article holds the British colonial legacy and the Muslim Hausa-Fulani political manipulative domination and its self-imposed superiority de facto status accountable as the propelling aggravating factors for the incessant political and religious conflicts and hostility in Nigeria. It concludes by proposing the application of divine moral laws by people in governance in order to achieve for the country a just, fair, equitable, and a cohesive Nigerian society of true brotherhood and nationhood.
\end{abstract}

KEYWORDS: Brotherhood, conflict, Edom, Edomites, HausaFulani, hostility, Israel, Nigeria, Obadiah, economic, political, religious

\section{A INTRODUCTION}

Conflict and hostility are recurring themes in the HB, spanning from the period of the patriarchs right into probably the postexilic Yehud community. ${ }^{1}$ The

* Article submitted: 1/09/2016; peer-reviewed: 1/11/2016; accepted: 26/01/2017. To cite: Joel Kamsen Tihitshak Biwul, "Brothers in Conflict: Reading the Prophet Obadiah Against the Context of the Political and Religious Hostility and Violence in Nigeria," Old Testament Essays 30/1 (2017): 30-55. Doi: http:// dx.doi.org/10.17159/2312-3621/2017/v30n1a4

1 In the book of Genesis alone, three major conflict situations are extant: the Abraham versus Lot conflict (Gen 13:5-12); the Esau versus Jacob conflict (Gen 25:25-34; 27:1-41); and the Joseph versus his brothers conflict (Gen 37:2-36). See discussion on the ethical value of tensions in Theodor Seidl, "Conflict and Conflict Resolution: Inner Controversies and Tensions as Places of Israel's Self-Conception in the Patriarchal Traditions of Genesis," OTE 26 (2013): 840-863. The concept of conflict in human society, fundamentally, points to the presence of the elements of furious clash, strong disagreement, opposition, or antagonism, initiated most times by the 
book of the prophet Obadiah emerged against the background of massive bitterness, malice, hatred and longstanding hostility between two brothers Esau and $\mathrm{Jacob}^{2}$ (Gen 25:25-34; 27:1-41; Exod 20:14-21; Obad vv. 10, 12); whose descendants, Judah and Edom, were relatives. The author of Obadiah projects the Edomites as the descendants of Esau, a blood brother of Jacob from the same mother. Esau was the one who became so embittered and who hardened his heart and stifled moral conscience against his brother (see Amos 1:11-12). But Obadiah is silent about the role of the Israelites, the descendants of Jacob, in the conflict. Such representation is an intriguing moral issue in this prophetic book. This context serves as the likely motivating factor for Phil J. Botha's proposal to view the book "... as a response to a specific social and theological situation in the history of the people of Israel." 3 James Limburg describes the Book of Obadiah from the perspective of the Esau-Jacob tradition as that of an important message about oppressors versus the oppressed and betrayers versus the betrayed. ${ }^{4}$ Also, Leslie C. Allen considers the message of this book as "... a theological necessity of reprisal for what the Edomites did to

failure to reason between two opposing groups or individuals. The aggravating force for such conflict situations is either provocation or the failure of social association of the two entities, either on the ground of misunderstanding, wrong assumptions, or imposition of superiority ideology. Ethno-tribal, intra-national and international tensions, and sometimes wars, largely hinge on these factors. Moving beyond the patriarchal traditions of Genesis, Jeremy Schipper links parables with conflict and suggests that "parables appear exclusively within stories of severe conflict ... [as] Each parable in the Hebrew Bible seems to address a severe conflict in some fashion," citing passages in books such as Judges, 2 Samuel, 1 \& 2 Kings, and more. See Jeremy Schipper, Parables and Conflicts in the Hebrew Bible (Cambridge: Cambridge University Press, 2009). Matthew Michael's assessment of angry scenes is also helpful here. See Matthew Michael (Rabbi Mikhail), “Anger Management and Biblical Characters: A Study of 'Angry Exchange' among Characters of Hebrew Narrative," OTE 28 (2015): 451-480.

2 The Esau-Jacob narrative shows Esau as the innocent sufferer of an unforeseen event while Jacob is portrayed as the shrewd manipulative beneficiary of his game, with his mother playing alongside as his benefactor. Much more, their progenies, Israel, is portrayed as a polite brother but Edom as an impolite "bad embittered brother" to Israel; thus, revealing the use of the principle of diplomacy and negotiation by the former which is blatantly rejected by the latter. For further discussion on this subject, see Edward J. Bridge, "Polite Israel and Impolite Edom: Israel's Request to Travel through Edom in Numbers 20.14-21," JSOT 35 (2010): 7788.

3 Phil J. Botha, "Social Values in the book of Obadiah," OTE 16 (2003): 581.

4 James Limburg, Hosea - Micah: Interpretation (Georgia: John Knox Press, 1988), 127. 
the people of Judah and Jerusalem." Clarence Hassell Bullock adds that, standing in the declarative prophetic tradition of the "Day of the Lord,"

Obadiah looked from the vantage point of the disaster that had befallen Jerusalem, reviewed its tragedy, and announced that the Day of the Lord was near for the nations, and for Edom in particular. $^{6}$

This was necessitated by Edom's betrayal of Judah and her acting “... contrary to accepted cultural protocols ..."7 of brotherhood relationship. Hence, Jeffrey J. Niehaus considers the book as a covenant lawsuit against Edom for its violation of fraternal relations. According to him, "The Edomites' violation of the covenant of kinship is, no doubt, the reason that Edom is mentioned in the Bible more than any other hostile nation,"8 except perhaps Egypt, Assyria and Babylon. This necessitates the establishment of Yahweh's justice as the primary message of Obadiah. ${ }^{9}$ To say the least, other OT parallels such as Ps 137:7; Lam 4:18-22; Ezek 25:12-14; and 35:1-15 all “... echo the furious resentment expressed in Obadiah at the way the Edomites took advantage of Jerusalem's subjugation by the Babylonians."10

This prophetic book portrays an unfolding story of persistent generational bitterness, anger, unabated malice, unforgiveness, vengeance and violence. It is a story that purports to work against the Jewish covenant principle of brotherhood and against the spirit of the Decalogue. Ethically, D. N. Premnath sees a xenophobic element in this book that cannot be condoned or justified. ${ }^{11}$ As Bullock points out, Edom's perfidious behaviour and scavenger approach to the devastation of Jerusalem compelled Obadiah to write his prophecy in reaction. ${ }^{12}$ In this sense, the book is basically a condemnatory oracle against Edom's act of swooping down upon wounded Jerusalem, taking advantage of her disaster in vengeance, and collaborating in plundering her in

5 Leslie C. Allen, The Books of Joel, Obadiah, Jonah and Micah, NICOT (Michigan: Eerdmans, 1976), 130.

6 Clarence Hassell Bullock, Introduction to the Old Testament Prophetic Books, updated ed. (Illinois: Moody, 2007), 308.

7 Botha, "Social Values," 582.

8 Jeffrey J. Niehaus, "Obadiah," in Obadiah, Jonah, Micah, and Habakkuk, ed. Thomas E. McComiskey, vol. 2 of The Minor Prophets: An Exegetical and Expository Commentary, ed. Thomas E. McComiskey (Michigan: Baker Academic, 1993; repr., 2006), 496.

9 Philip P. Jenson, Obadiah, Jonah, Micah: A Theological Commentary (London: T \& T Clark, 2008), 7.

10 Douglas Stuart, Hosea - Jonah, WBC 31 (Texas: Word, 1987), 404.

11 Joel D. N. Premnath, "Obadiah," in The Old Testament and Ethics, ed. Joel B. Green and Jacqueline E. Lapsley (Michigan: Baker Academic, 2013), 145.

12 Bullock, Introduction, 311. 
her time of helplessness. ${ }^{13}$ Other prophetic texts equally align with Obadiah on this point of divine retribution on Edom's injurious relationship with Israel (Jer 49:8-10; Isa 34:5-12; Lam 4:21-22; Joel 3:19; Mal 1:4). It also portrays the vicious and capricious behaviour of Edom toward the Israelites for which Yahweh's judgement was to be visited upon her. The cruelty which Edom exhibited in her relationship with Israel leads J. Daniel Hays to suppose that Edom is a symbolic representation of all the nations of the world that will come under Yahweh's judgement. ${ }^{14}$ Similarly, she could also be a symbolic representation of antagonistic evil against good being exhibited by the human behaviour of hate and betrayal in the society.

Older scholarship had observed that the corpus of the Minor Prophets hitherto had not benefited from the privilege of great prominence in the history of biblical interpretation for several reasons: these prophets are preoccupied more with nations and events of less relevance to the modern world; their dirge that celebrates the downfall of an ancient city lacks edification for a modern Christian; the gloomy forecasts of their message of captivity for Israel and Judah fail to lift the heart of the modern reader; and particularly, "... these prophets often expressed themselves in culturally and historically conditioned forms that seem foreign to [the modern reader]." 15 In recent scholarship, however, such assumptions are no longer tenable. In explaining the benefits of what he calls a "heuristic frame" approach to the study of prophetic constructions of the past, Ehud Ben Zvi notes,

... above all, the reason is that all prophetic books provide images of the past. All are set in the past, as are the divine or human utterances that they report. Moreover, through their reading and rereading of prophetic books, the literati, who constituted the primary readership of the prophetic books, could not but evoke, develop, shape, and reflect images of the past. ${ }^{16}$

13 Bullock, Introduction, 312, 311. Here, if "one good turn deserves the other," the measure of evil that one heaps on another is always meted back. Just as Jacob took advantage of his twin elder brother in his hour of need, so did Esau also take advantage of Judah in her hour of need; thus, completing the circle of revenge. See Joachim J. Krause, "Tradition, History, and Our Story: Some Observations on Jacob and Esau in the Books of Obadiah and Malachi," JSOT 32 (2008): 476.

14 J. Daniel Hays, The Message of the Prophets: A Survey of the Prophetic and Apocalyptic Books of the Old Testament, ed. Tremper Longman III (Michigan: Zondervan, 2010), 298.

15 Thomas E. McComiskey, "Introduction," in Obadiah, Jonah, Micah, and Habakkuk, ed. Thomas E. McComiskey, vol. 2 of The Minor Prophets: An Exegetical and Expository Commentary, ed. Thomas E. McComiskey (Michigan: Baker Academic, 1993; repr., 2006), xi.

16 Ehud Ben Zvi, "De-Historicizing and Historicizing Tendencies in the Twelve Prophetic Books: A Case Study of the Heuristic Value of a Historically Anchored 
Göran Eidevall's recent study on prophetic view on the cult of sacrifice in Israel substantiates the point. ${ }^{17}$

To this extent, the relevance of the corpus of the Minor Prophets to the Nigerian society and for the modern African reader is extant. For instance, when one reads the text of Obadiah, one is left with the feeling that this prophet appears to have been an African, and specifically, a Nigerian. Although the message of Obadiah has great relevance for the African and Nigerian situations ${ }^{18}$ for the resemblances the Obadian and Nigerian contexts share, yet Nigerian biblical scholars particularly have not given much space to it. They have not taken serious cognisance of the similarities of the root cause of ethnic or tribal violence in this prophetic corpus vis-à-vis what plays out in the Nigerian experience of political and religious hostility and violence. Reflectively, if prophet Obadiah took on a dirge of lamentation in confronting the narrated evil committed by Edom against Judah in negation of the principle of brotherhood, this dirge is relevant to the Nigerian context of political and religious maiming and killing. But if, on the contrary, he preached a condemnatory sermon against Edom and simultaneously followed with another consolatory sermon for Judah, this also is quite fitting for the prevailing Nigerian situation of bitterness and distrust, ethnic and political hatred, and growing social and religious hostility and violence where both victor and vanquish are involved.

Using a historical and theological approach in this research, this article first investigates the factors that accounted for the narrated devastating darts of persistent hostility in the Book of Obadiah. It follows by interpreting its resemblances against the context of continual tribal strife, regional and ethnic violence, and economic, political, and religious hatred, hostility, and violence in contemporary Nigerian experience. Secondly, the article identifies the contributory factors that have both precipitated and facilitated such a prolonged hostility that has infiltrated all facets of the Nigerian state, its effects on the desired social, ethnic and religious cohesiveness of the country, and how it has thwarted the regional and national political synergy expected of a normal society.

Systematic Approach to the Corpus of Prophetic Literature," in Israel's Prophets and Israel's Past: Essays on the Relationship of Prophetic Texts and Israelite History in Honor of John H. Hayes, ed. Brad E. Kelle and Megan Bishop Moore, LHBOTS 446 (New York: T \& T Clark, 2006), 38

17 Göran Eidevall, Sacrificial Rhetoric in the Prophetic Literature of the Hebrew Bible (New York: Edwin Mellen, 2012).

18 Although Edom was not a major player in the ANE historical drama, yet a whole prophetic book is concerned with it because of its ethical relevance to society. Even the conservation of the Obadiah corpus, presumably in its original form, speaks to its theological significance. See Daniel I. Block, Obadiah: The Kingship Belongs to YHWH (Michigan: Zondervan, 2013), 105. 


\section{B THE HISTORICAL ROOT OF BROTHERHOOD HOSTILITY IN THE BOOK OF THE PROPHET OBADIAH}

It is observed from the content of this prophetic book that Obadiah, "servant of the Lord," undoubtedly, was "... acquainted with a stock of prophetic sayings upon which he drew" for his own prophetic message. ${ }^{19}$ Yet, his prophetic message functions in its own right. The retrogressive and reflective nature of his prophecy, particularly at the probable historical timeframe for this prophetic activity, most fitting as a postexilic prophet (539 BCE), attests to this. ${ }^{20}$ Prophet Obadiah is not only unique in his own right but his prophetic oracle also is crucial to the history of Judah vis-à-vis the prophet's motivating agenda and propaganda for prophesying. He stands in the prophetic tradition as the Lord's messenger in his use of the introductory formula, "Thus says the Lord."

The historical context, in the light of the two dominant player nations Judah and Edom, fairly best dates the prophecies of Obadiah to the exilic period between the fall of Jerusalem in 586 BCE and Edom's demise at the hands of the Babylonians in 553 BCE. $^{21}$ The beneficiary community of Obadiah's prophetic ministry is most likely the remnant returnees of the early postexilic community. Following this line of thought, Allen describes the psychology of this community thus:

19 Limburg, Hosea - Micah, 128. Some suspect that Obadiah borrowed from Jeremiah while others suppose that both prophets drew from the same source. The proof for either depends on ascertaining the identity of the prophet and the historical period of his existence and ministry.

20 Six theories about the historicity of the probable period of Obadiah's prophetic preaching have been proposed: first, it is situated at a time when Jerusalem surrendered to Shishak in the fifth year of Rehoboam (931-913 BCE); second, it is located during the invasion of Judah by a coalition of Arabs and Philistines when Jehoram was reigning (853-841 BCE); third, it was during the reign of Joash (835-796 BCE) when the Syrians caused widespread destruction in Judah; the fourth proposal situates it at a period when Amaziah was king (796-767 BCE) and Judah's treasure and hostages were seized in an open conflict with Edom; fifth, it was at a time during the reign of Ahaz (735-715 BCE) when Judah was increasingly threatened by foreign powers; and the last was during the period of the demise of Jerusalem when Judah was invaded by Babylon and her inhabitants were taken captive in 586 BCE. Although Block speculates that "... the book was produced at a time when [the] Edomites were a problem for those who made up the covenant community in and around Jerusalem," Block, Obadiah, 22-24, we must first be able to clearly distinguish the period of the oracular declaration and its final production to arrive at a reasonable conclusion. Philip P. Jenson suggests that, an "... early exilic dating is both historically likely and fruitful for a richer interpretation. It allows our understanding of the text to be informed by what else we know of the exile." Jenson, Obadiah, 5.

21 Block, Obadiah, 24. 
The nation, a shadow of preexilic glory, was struggling for its very existence and fighting overwhelming problems on political, territorial, and economic fronts.... Through Obadiah, Yahweh understandingly gives a word for the times. He soothes festering mental sores which developed from national humiliation. ${ }^{22}$

In this connection, as Limburg suggests, this prophetic text is a sermon delivered by the prophet "... to the gathered postexilic community at a service of memorial for the temple," stressing Edom as "... one of those enemies responsible for all that had happened to [Jerusalem]." ${ }^{23}$ But Obadian critics would query why the prophet shifts blame from Judah to Edom like people who look for a scapegoat for Judah's misfortunes. Instead of shifting blame, the prophet would also have confronted the Judean community for her infidelity towards Yahweh, a fundamental factor that facilitated the Babylonian captivity. This notwithstanding, even if the suggestion lacks certainty, when we follow the tone and rhythm of the prophetic narrative, it appears more appealing to assume that Obadiah was reflecting back to the fall of Jerusalem in $586 \mathrm{BCE}$, in which Edom was clearly implicated ${ }^{24}$ for her part in the fall of Judah (see vv. 10-15; see also Jer 40:11-12; Ezek 25:12-13; 35:15; Amos 1:11-12).

\section{The Climate for Brotherhood Hostility in Obadiah}

The tension in the Esau-Jacob narrative tradition (Gen 25-27) is one that is rightly perceived as “... not edifying in any conversational religious or moral sense." 25 Particularly, Yahweh's choice and perpetuation of the Abrahamic covenant through Jacob and not Esau, overturning conventional natural rights and privilege, is a moral enigma ${ }^{26}$ (Gen 25:21-26; Mal 1:1-4). These texts reveal that "YHWH himself subscribes to the role reversal and has the secondcomer Jacob supplant his brother Esau." 27 Such a divine role in what would later become a longstanding conflict in the relationship between the descendants of Esau and Jacob poses a great moral problem in the prophetic text of Obadiah. Here, the morality of the prophetic condemnatory oracle, dirge, or sermon against Edom in the phraseology of "the day of the Lord" is at risk (vv. 8, 15).

\footnotetext{
22 Allen, Books of Joel, 138.

23 Limburg, Hosea-Micah, 131.

24 Carl E. Armerding, "Obadiah," in The Expositor's Bible Commentary, vol. 7, ed. Frank E. Gaebelein (Michigan: Zondervan, 1985), 351.

25 Walter Brueggemann, Genesis, IBC (Georgia: John Knox Press, 1982), 204.

26 Though apparently simplistic, such enigma may partially be resolved by Brueggemann's suggestion that, "The narrative invites the listening community to marvel rather than to explain" or to even question; for answers, in this context, will not readily be available to the one who questions. See Brueggemann, Genesis, 235.

27 Krause, "Tradition," 476.
} 
While such a divine scandal of choice, at the human level, is the lead conflict factor in this narrative, we also notice that, "the two parents who prayed so passionately for a son [but who] have now taken sides," 28 obviously are equally responsible for causing the conflict between their two sons (Gen 25:27-28). Parents are morally bound to inculcate good morals in their offspring. They are also expected to function as the vanguard and the moral conscience of their children. Serving as the first and major influencers of their offspring as role models, what parents say and do would normally either make or mar their children and their future. The negative aspect of parental influence is quite glaring in the family of Isaac (Gen 25:19-28). Gordon Wenham points out that Isaac's love for food exacerbates the tension between the rival brothers and Rebekah's favouritism further aided this rivalry. As an opportunist, just as Jacob himself was, Rebekah used her husband's appetite and Jacob's tractability to acquire the blessing for the son she loved. ${ }^{29}$ The act of favouritism and segregatory treatment of children stands out as another major factor of what would later play out in the text of the prophet Obadiah. Clearly, then, parental segregation and discrimination of children on the basis of a "favourite child" ideology posed a generational sociological challenge to relationships that can hold grievous long-lasting detrimental effects as was the case with Isaac's family.

On the other hand, however, the birth narrative in Gen 25 suggests that Isaac and Rebekah appear in the Esau-Jacob narrative only as agents who facilitated an already existing theme of conflict in Genesis. Here, we see the occurrence of conflict between Cain and Abel (Gen 4:1-8), the sons of Noah (Gen 9:20-27), Abraham and Lot (Gen 13:7-12), Isaac and Ishmael (Gen 2931), and the conflict between Joseph and his brothers (Gen 37-50). Additionally, moving away from the theme of brother-brother conflict to that of the family, the biblical account also reveals that the root of familial hostility dates back to the descendants of Ishmael who had lived in hostility toward all their brothers after the demise of their father (Gen 25:18). While the hostility of Ishmael's descendants is in fulfilment of the angelic proclamation: "He will be a wild donkey of a man; his hand will be against everyone and everyone's hand against him, and he will live in hostility toward all his brothers" (Gen 16:12 NIV); that of Esau against Jacob (Edom and Israel) has its root in parental favouritism. The biblical narrative introduces this idea when it reports that Isaac loved Esau while Rebekah loved Jacob (Gen 25:28).

The narrative also presents the roles of Esau and Jacob in the tension. Esau's lack of a thoughtful and critical decision prepared the ground for Jacob's shrewd and manipulative character to come to prominence. Here, Esau is indicted both for the loss of his natural birth right and the conflict that later

28 Brueggemann, Genesis, 217.

29 Gordon J. Wenham, Genesis 16-50, WBC 2 (Texas: Word, 1994), 177. 
ensued because he despised what is valuable (Gen 25:34). Wenham draws attention to the fact that it was Esau who exhibited a careless indifference to a privilege that the ancient world held dear. ${ }^{30}$ John H. Sailhamer argues equally, “... when in God's plan Esau lost his birth right and consequently his blessing, there was no injustice dealt him. The narrative has shown that he did not want the birth right. He despised it." 31 But by the same token, when we plot the narrative within the divine schema, as it plays out, one wonders if another reversal would have been possible had Esau not "despised" his natural rights and privilege. Even then, for Jacob to have demanded for some form of payment from his hungry elder brother before playing hospitality to him reveals his act of disrespect, greed and manipulative attitude, which amounts to forceful robbery (Gen 25:29-34). After all, he is described as a shrewd trickster who has a reputation for cheating. ${ }^{32}$ Rebekah's acting as Jacob's benefactor also precipitated his evil manipulative behaviour toward his brother and father (Gen 27:5-13). Jacob then played the "good boy" when he executed his mother's egocentric and thoughtless plot (Gen 27:14-30). Rebekah's action did not take into account what the immediate and future effects of her egocentric scheme would have upon the relationship of her two sons and their descendants (Gen 27:41).

The story of this family, as scholarship observes, “... is one of parental favo[u]ritism, which tore their family completely apart." 33 It is a story that shows "... human behaviour and motives at their worst: favouritism, deceit, foolish credulity, and murderous vindictiveness." 34 Here is a story that marks the beginning of a distorted familial relationship that degenerated finally into generational hostility and constant aggression in search of vengeance. Such a deepened relational conflict between the descendants of Esau and Jacob is serious enough to become a major theme in the prophets (Isa 34:1-17; 63:1-6; Jer 49:7-22; Lam 4:22; Ezek 25:12-14; 35:1-15; Amos 1:11-12; 4:21-22; 9:1112; Joel 3:19; 4:19-21; Mal 1:2-5), even in the Psalms (Ps 137:7).

In sum, when Obadiah is read before Genesis, not as a polemic but as a recitative reflection of a historical event, readers may likely notice that the storyline is clustered with deception, conspiracy, insensitivity, manipulation,

30 Wenham, Genesis 16-50, 178.

31 John H. Sailhamer, "Genesis," in The Expositor's Bible Commentary, vol. 2, ed. Frank E. Gaebelein (Michigan: Zondervan, 1990), 185.

32 Krause, "Tradition," 475.

33 Allen P. Ross, "Genesis," in The Bible Knowledge Commentary: Old Testament, ed. John F. Walvoord and Roy B. Zuck (Wheaton: SP Publications, 1987 [1985; repr.]), 73.

34 David F. Payne, "Genesis Chapters 12-50," in The International Bible Commentary, new ed., ed. Frederick F. Bruce (Michigan: Marshall Morgan \& Scott, 1986), 132-133. 
and self-centredness. It is plotted against the scene of divine scandal, parental favouritism, Esau's carelessness, and Jacob's manipulative scheming.

\section{The Generational Effects of Brotherhood Hostility}

The dominant words such as Lord, Edom, and Israel form the frame of the book of Obadiah. Limburg is right in positing that the main subject of the book is Edom. As such, a background historical knowledge of the relationships between Edom and the Israelites will facilitate better understanding of the book of Obadiah and the events encapsulated therein. ${ }^{35}$ As the main culprit, Edom is charged, not only for acting as Israel's betrayer but also as its enemy during the fall of Jerusalem (586 BCE), though a close relation of Judah (vv. 11-14). Armerding, however, sympathetically exonerates Edom from any blame of active participation in Judah's catastrophe. He holds rather that the role of Edom expressed in vv. 12-14 lays emphasis more on its hostile attitudes rather than on its physical violence at Jerusalem during Judah's catastrophe. He argues particularly on the strength of v. 11 that Edom was accused on the basis of intent and not explicitly on their active involvement in the sack of Jerusalem. According to him, Edom is accused and charged for her participation when she acted "... as a mocking bystander and as a collaborator with the foreign invaders, so betraying an existing bond of loyalty with Judah." 36 Like Armerding, Juan M. Tebes also argues that a close scrutiny and a re-reading of the Obadian text that faults Edom for her active role in Judah's downfall of 586 BCE reveal, on the contrary, a lack of important factual details but is rather full of "... theatrical imagery that is a product of their negative attitude towards Edom." 37 Other critical scholars such as Elie Assis would also argue that Obadiah had placed a political agenda before the postexilic reading community. For instance, while Assis acknowledges that the earlier oracles of Obadiah were not overturned, yet the author revised his treatment of Edom vis-à-vis the occurring political changes of his time so he could better respond to such political realities. ${ }^{38}$

35 Limburg, Hosea-Micah, 129.

36 Armerding, "Obadiah," 349-350.

37 Juan M. Tebes, "The Edomite Involvement in the Destruction of the First Temple: A Case of Stab-in-the Back Tradition," JSOT 36/ (2011): 220.

38 Elie Assis, "Structure, Redaction and Significance in the Prophecy of Obadiah," JSOT 39 (2014): 209-221. Assis considers the book of the prophet Obadiah as consisting of three oracles, each reflecting a different historical time period. While the first oracle critiques the pride of Edom in a pre-destruction period of Judah, the second reflects on Judah's hostile reaction to Edom for her participation in the event of 586 BCE. The third oracle reflects a postexilic encroachment of Southern Judah by the Edomites. What plays out in these three oracles is the prophet's unequivocal attribution of Edom's aggressive attitude against Judah for which divine retribution is inevitable. 
However, the several mentions of Edom in the biblical text, largely with negative undertones, seem more reasonable to concede that Edom played a negatively active rather than a passive role in a graduating fashion during the unfortunate plight of his blood brother. Israel and Edom already had a strained relationship and had lived in hostility for centuries. Consequently, like a scavenging predator lying in wait to pounce on its prey, Edom executed his ethnic vengeance when he took advantage of the situation and actively collaborated with the Babylonian world power in its aggression against Judah. ${ }^{39}$ Verses 1114 reveal Edom's crimes, as W. Ward Gasque explains: this dirge-like passage indicts Edom for standing aloof instead of coming to the aid of Judah during her plight; Edom looked on the plight of Judah with malicious satisfaction; he even joined in the looting of Jerusalem; worst, in spite of blood-ties with Israel, he behaved like the invading enemy of strangers. Such a treacherous act toward Judah reached its extremity when the Edomites refused to grant asylum to Judah's fleeing refugees, but instead, handed them over to the destroying enemy, ${ }^{40}$ probably killing some of the helplessly vulnerable refugees. This is the height of their prolonged hostility; for

The Israel-Edom/Esau national relationship is fraught with as much tension as occurred between the brothers from whom they were descended. Though biologically 'family,' blood did not preclude bickering. ${ }^{41}$

When the prophetic narrative of Obadiah is considered at its face value, it seems clear that the bitterness and vindictiveness of a progenitor has the likelihood of becoming like a genetic heredity in the progeny. Such progenitorial relentless bitterness and unabated hatred expressed toward an offender, worse, one from the same family line, is likely transferable from generation to generation. According to the Esau-Jacob tradition, although Esau later reconciled ${ }^{42}$ with his brother Jacob (Gen 32:3-33:18), the effects of their

39 David W. Baker, Joel, Obadiah, Malachi, NIVAC (Michigan: Zondervan, 2006), 145.

40 W. Ward Gasque, "Obadiah," in The International Bible Commentary, ed. Frederick F. Bruce, new ed. (Michigan: Marshall Morgan \& Scott, 1986), 915. Such intense cruelty leads Walter L. Baker to the assertion that, "The animosity between the Edomites and the Israelites is one of the oldest examples of discord in human relationships." Walter L. Baker, "Obadiah," in The Bible Knowledge Commentary: Old Testament, ed. John F. Walvoord and Roy B. Zuck (Wheaton: SP Publications, 1987 [1985; repr.], 1454

41 Baker, "Obadiah," 150.

42 Bridge understands "Jacob's use of servile language to Esau" to mean an attempt to exonerate himself from his past wrong by encouraging Esau in their treaty to "forego his right of revenge" and also to "remove himself from being with Esau." This brings to question the genuineness of his repentance after his encounter with Laban. See further discussion in Edward J. Bridge, "The 'Slave' Is the 'Master': Jacob's Servile Language to Esau in Genesis 33.1-17,” JSOT 38 (2014): 263-278. 
past hostility still lingered and marred the relationship of their offspring. This is clear from the storyline that was later replicated in the ethnic national tension and strife between the Edomites and the Israelites (see Gen 27:41; Num 20:14-

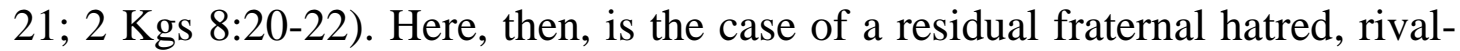
ry, ${ }^{43}$ and ancestral animosity ${ }^{44}$ between the lineal descendants of blood brothers.

But, as Jeremiah, Ezekiel, Amos, and Obadiah claimed (Jer 49:7-17; Ezek 25:12-14; Amos 1:11-12; Obad vv. 10-14), the evil committed by Edom against the Judeans is soon to be visited upon him to capture the maxim, "The evil that men do lives after them." He is to come under divine judgement, not necessarily because his historical ancestry was offended and cheated, but because he remained vengeful; and consequently, acted with violence toward Jerusalem and Judah against the tie of brotherhood (see Deut 23:7, 20; 15:2-3, $7-9 ; 2: 8$; see also Gen 4:9-11). What is material in Edom's condemnation is the antagonistic element captured in what Bert Dicou calls his inimical behaviour and reproachable attitude ${ }^{45}$ toward Judah's catastrophe. Divine retribution was imminent on the basis of his attitudes and actions ${ }^{46}$ with regard to Judah because Edom's breach of genealogical relationship with Judah necessarily strained his relationship with Yahweh. ${ }^{47}$ As a consequence, as Henk Potgieter points out, "The message of the book of Obadiah is that Yahweh will punish the treacherous and arrogant actions of the Edomites"48 against Judah. Subsequently, many years after this evil was committed by Edom (about two hundred and seventy-four years), Yahweh used the nomadic Nabatean Arabs and the army of Antigonus to also attack and take over Mount Seir the capital of Edom in $312 \mathrm{BCE}$. This was to bring to fulfilment the prophetic oracle of doom contained in Obadiah's prophecy of Yahweh's acting in vengeance on behalf of Judah. This suggests that the initial onslaughts upon Mount Seir by the coalition of the nomadic Arab tribes, led by Qedar, brought Edom to its knees and final demise in or shortly after 312 BCE. Here, we can be certain that in divine economy, no wrongdoing goes unpunished by Yahweh, just as by the same token, no good deed goes unrewarded by him. The moral principle for functional human relationships and for a good society is, therefore, to do good to all people as one would like to reciprocally have it done (see Matt 7:12).

43 Baker, "Obadiah," 156.

44 Niehaus, "Obadiah," 496. The mention of fraternity of Edom and Israel is found in Gen 25; 27; 36; Num 20:14; Deut 2:4, 8; 23:7; Amos 1:11; and Mal 1:2. Also, the mention of animosity and enmity that existed between these relatives - Edom and Israel, is found in Num 20:18-21; 1 Sam 14:47; 2 Sam 8:12-14; 1 Kgs 11:14-22; Amos 1:11; and Mal 1:3.

45 Bert Dicou, Edom, Israel's Brother and Antagonist: The Role of Edom in Biblical Prophecy and Story (Sheffield: JSOT Press, 1994), 13, 26.

46 Bradford A. Anderson, "Poetic Justice in Obadiah," JSOT 35 (2010): 247-255.

47 Botha, "Social Values," 590.

48 Henk (J. H.) Potgieter, “A Poetic Analysis of Obadiah,” OTE 16 (2003): 666. 


\section{INTERPRETING THE TEXT OF OBADIAH WITHIN THE NIGERIAN CONTEXT OF SUSPICION AND HOSTILITY}

The gradual but massive amalgamation of the Northern and Southern Protectorates in 1914 by the British colonialists into a country now called Nigeria ${ }^{49}$ achieved both positive and negative results. While the political and economic goal of the effort was achieved at the time, the ethnic, social and religious aspects still remained an area of challenge. Even the euphoria of the political independence granted to the country on October 1, 1960 only lasted for a moment; for the country, shortly afterwards, relapsed into protective sectional identity and regional self-interest politically, economically, and socially. Consequently, since 1960 up until the present, there still remain several factors of persistent friction and ethnic tensions among the ethnic and tribal people of the land. The first was the Nigerian civil war. When the political upheaval that engulfed the nation led to the massive killing of Igbos in the North, the reaction by the affected ethnic group was the declaration of the Independent Republic of Biafara on May 30, 1967. The civil war that ensued from July 6, 1967 to January 5, 1970 was consequent upon the failure of diplomatic efforts to resolve the conflict. Recently also, the upsurge of regional pressure groups such as the Afenifere in the South-West, the Bakasi Boys in the South-South, the resurgent agitation for the Movement for the Biafara State in the South-East, and Boko Haram in the North-East are new faces of the challenge.

By divine providence, however, the amalgamation not only placed Nigeria on the world map as the most populous black nation of the world, it also brought all ethnic stalks and tribal peoples into one family - the Nigerian national family and brotherhood. The first stanza of the first national anthem of 1960-1978 captures this well:

Nigeria we hail thee,

Our own dear native land,

Though tribe and tongue may differ,

49 The process of amalgamation of British administrative units began gradually but purposefully. Two territories - the Lagos Colony and Protectorate and the Protectorate of Southern Nigeria, were first amalgamated in May 1906 to form the new Protectorate of Southern Nigeria. Lastly, both Southern and Northern Protectorates were amalgamated in January 1914. Such a politically and economically motivated venture was not, however, without pockets of resistance, as the British administration did not consider it material to first seek the consent of the affected peoples of the various regions. For further details, see Tekena N. Tamuno, "British Colonial Administration in Nigeria in the Twentieth Century," in Groundwork of Nigerian History, ed. Obaro Ikime (Nigeria: Heinemann, 1980; repr., 2004), 393-409; Tekena N. Tamuno, The Evolution of the Nigerian State: The Southern Phase, 1898-1914 (London: Longman, 1972); Ian F. Nicolson, The Administration of Nigeria, 19001960 (Oxford: Clarendon, 1969). 
In brotherhood we stand,

Nigerians all, and proud to serve

Our sovereign Motherland.

The assertive affirmation is that although we are different people from different ethnic and tribal lineages, yet we will stand in brotherhood as one national family, "Our own dear native land." The second national anthem adopted in 1978 also corroborates the fact that, as one nation that is bound in freedom, peace, and unity, all Nigerians are to serve their father's land, Nigeria. This assumes the principle of nationhood as a unifying force for the stay of the state.

Yet, as a nation with many ethnographic tribal groupings, and numerous lingering anthropological challenges, she is supposed to be bound by unity and brotherhood. These challenges account for the frequent ethnic or tribal conflicts and incessant economic, political, and religious violence it has witnessed through her history. Accordingly, Ukoha Ukiwo notes that Nigerians have adapted to the reality of conflicts and violence rather than being surprised at their outbreak. ${ }^{50}$ While the hostility and violence narrated in the Book of Obadiah is situated within the context of a national strife that has its roots in a prolonged ancient strained familial relationship, the one in the Nigerian society is multifaceted both in its historical roots and by its nature. It ranges from regional, social, ethnic or tribal, economic, political and religious factors. These are considered below in comparison with the text of Prophet Obadiah.

\section{The Political and Economic Dimensions of the Issue}

Historically Nigeria came to be through the merger or fusion of two major parts, North and South, with embedded smaller parts into one country. The term Northern and Southern Protectorates was an administrative creation of the British colonialists to achieve their political purposes. The people from these Protectorates, with their ethnic or tribal and cultural distinctiveness, were collapsed to form Nigeria, yet not conscious of what its present and future effects would likely become. In the case of the North, Sa'ad Abubakar explains,

Before the present country, what was formerly known as Northern Nigeria comprised a number of independent entities. The leading ones being the Sokoto Caliphate and the Borno Empire. There were also a number of states, chieftaincies and innumerable communities in varying scales of political organization. These existed to the south

50 Ukoha Ukiwo, "Politics, Ehno-Religious Conflicts and Democratic Consolidation in Nigeria," JMAS 41 (2003): 16, doi: 10.1017/S0022278X02004172. 
of Borno and the Sokoto Caliphate, mainly on the central highlands and in the Niger-Benue valley. ${ }^{51}$

Against this background of a forceful marriage of political convenience by the British, Sunday Agang asserts that ethnic, religious, and political violence have radically contributed to the changing face of the Nigerian culture, religion, and politics. Consequently, it has permeated her various systems, thus, becoming part and parcel of the country's daily morality. ${ }^{52}$ When incessant violence becomes a norm and the moral value of a people, the act of aggression and the language of hostility would inseparably lie underneath the lifestyle of such a people. These two misnomers will obviously either directly or indirectly guide the people's new worldview and their expressions in the society. To cite a distant but similar example, this seems to be the case with the experience in the Middle East and in modern Palestine in relation to the Israelite state.

The expression of political and economic hostility and violence in Nigeria is basically rooted in the power struggle of regional politics and politicians competing to "... capture more political clout and control of the economic resources of the country." It is this political power quest that has resulted "... in the politics of numbers, which seeks to use the highest number of voters by using demagogic divisiveness." ${ }^{53}$ The person that has the economy of the state controls its political power. Hence, the struggle for resource control such as oil in Nigeria is a fierce one.

Another case could be made for what Eghosa E. Osaghae describes as the extractive policies of the colonial regime. ${ }^{54}$ The British amalgamation of the regional administrative units in the North, and later of all the Protectorates, put in place some form of discriminatory superiority status quo that created some misgivings amongst ethnic groups. The already established traditional Islamic administrative system of the Muslim "Core North," comprising of the western and eastern parts of the North, was not altered by the colonialists, but was rather strengthened and imposed on the mostly Christian minorities, especially of the Middle Belt extraction. This socio-political weakness was to later germinate the seed of suspicion and distrust, discord, conflict, hostility, bigotry, aggression, and violence in the whole country. For instance, when the Muslim "Core Northerners" characteristically assume political superiority and

51 Sa'ad Abubakar, "The Northern Provinces Under Colonial Rule: 1900-1959," in Groundwork of Nigerian History, ed. Obaro Ikime (Nigeria: Heinemann, 1980; repr., 2004), 447.

52 Sunday Bobai Agang, The Impact of Ethnic, Political, and Religious Violence on Northern Nigeria, and a Theological Reflection on Its Healing (Cumbria: Langham Monographs, 2011), 1-2.

53 Agang, Impact, 6.

54 Eghosa E. Osaghae, Nigeria Since Independence: Crippled Giant (Indiana: Indiana University Press, 1998), 48. 
dominance, as is the case today in Nigerian politics, the "Others" would react sharply and resist such a capricious act of a de facto status imposition. This then gave rise to what Agang calls intra-regional rivalry and competition which became the arena of the politics of exclusion. ${ }^{55}$ As a consequence, Nigerian political expression has become a game of semantics in the place of pragmatics to the benefit of regional and personal interests. It operates more on the ideology of manipulation than on the principle of negotiation and persuasion. This then brings to question the moral integrity of those politicians who say one thing but mean the other; or those who only aim at political correctness against the principle of sincerity of intent and moral conscience. Such a norm in itself creates the basis for ethnic and regional hostility.

Unfortunately, the colonial political legacy of raising the Muslim HausaFulani in the North to a superior de facto status while at the same time subjugating the non-Muslim ethnic minority groups, particularly in the NorthEast but majorly in the Middle Belt to an inferior status, according to Yusuf Turaki, unavoidably, has its long-term consequences for post-colonial Nigeria. ${ }^{56}$ The colonial administrative system of indirect rule failed to create any conducive political climate of equal, just and fair participation that would give the minority ethnic groups “... any reasonable socio-political role in the colonial system, instead, they were systematically subordinated to HausaFulani rule and political control." 57 Unknown to them, the Muslim HausaFulanis were to use ethnicity to their political advantage since the Nigerian version of politics is ethnic oriented. ${ }^{58}$ This socio-political blunder was grounded in the colonialists' misjudgement that other ethnic groups "... did not have elaborate centralized political structures like the Hausa-Fulani [had]..."59 Consequently, the anti-sociological, anti-cultural and political imposition of Muslim Hausa-Fulani rulers by both the colonialists and the Muslim Hausa-

55 Agang, Impact, 12.

56 Yusufu Turaki, The British Colonial Legacy In Northern Nigeria: A Social Ethical Analysis of the Colonial and Post-Colonial Society and Politics in Nigeria (Nigeria: Challenge, 1993), 1. Turaki defines "colonial legacy" as "... the colonial philosophy of nation-state building which used racial, ethnic or tribal, religious and cultural values to establish a colonial social order." See Turaki, British Colonial Legacy, 7.

57 Turaki, British Colonial Legacy, 2. The agenda of the Muslim Hausa-Fulani extraction of the north, since the time of the Sardauna of Sokoto and the Premier of Northern Region, Alhaji Ahamadu Bello, has been to retain political power in the north, and by and large, of the whole country through religious leverage via the machinery of Islam. The emergence of Islamic organisations such as the Council of Ulama and Jama'atul Nasir-Islam, for example, are some of these machineries. For further details, see Olufemi Olayinka Oluniyi, The Council of Ulama and Peaceful Co-existence in Nigeria (Lagos: Frontier, 2006).

58 Peter O. Kalejaiye and Nurudeen Alliyu, "Ethnic Politics and Social Conflicts: Factors in Nigeria's Underdevelopment," JISR 6 (2013): 252.

59 Turaki, British Colonial Legacy, 2. 
Fulani group led to gross physiological, sociological, psychological, and economic enslavement and brutality which was later to result in reprisal by the oppressed in the form of aggression, hatred, hostility, and violence in the postcolonial era. This already inflammable atmosphere is further aggravated by the patrimonial $^{60}$ approach to governance by the Muslim Hausa-Fulani extraction in the political space. Such ethno-tribal tension is a generational legacy that would hardly be defused, corrected, and forgotten as it now stands as a social and political unhealed scar. For instance, the recent increasing escalating political and religious violence in several parts of Nigeria such as Plateau and Kaduna states, is an affirmation of such social and political consequences, especially the politically and religiously precipitated attacks on the North-East and Middle Belt by Muslim Fulani herdsmen, disguised under an ethnic one.

Unlike the ethnic national situation narrated in Obadiah, the Nigerian people come from different ethnic and regional parental stalks. The root cause of their internal social, political, and religious hostility, therefore, is located in the imbalanced attitude and expression of superiority-inferiority ideology. This misnomer is heightened by the expression of societal class stratification or status differentiation; by social separation through ethnic and religious identity codification (stigmatisation); and by the intentional treatment of citizens by governments on the basis of ethnic and regional inequality. Such ideology is further extended to the religious expression of preferential treatment in terms of admission, recruitment, appointment, development, and elections. These social, political, and antidemocratic imbalances have spiced up suspicion and distrust, leading to unnecessary aggression and violence, sporadically expressed, even, unfortunately, on the floor of the national assembly. Such an unfortunate situation is best captured by the paradoxical description of Nigeria by Samson Olanisebe as a privileged country that produces wild grapes in a fertile garden. ${ }^{61}$

The economy is also another inflammatory area of challenge for the Nigerian state. It is quite glaring that the person who controls the economy is likely to also control the political power of a state. Unarguably, the continuous struggle for political control at the centre and resource control by the Northern and Southern divide is becoming more dangerous for the posterity of the

60 Nyirimana has argued that patrimonialism, serving as the cause of the dissolution of United Israel, is one basic factor for social conflict in the Rwandan context. Similar situation exists in the Nigerian context where loyalty in governance is fundamentally to kinship and ethno-tribal, and for the Muslim North, to religious ties. Eraste Nyirimana, "Patrimonialism in the Causes of the Division of the Kingdom in Israel: A Reading of the Division Narrative from the Perspective of the Rwandan Context of Social Conflict," OTE 24 (2011): 708-730.

61 Samson O. Olanisebe, "The Justice of God in his Anger: A Narrative Analysis of Isaiah 5:1-7 and its Implications for Socio-Economic and Security Challenges in Nigeria," OTE 28 (2015): 492. 
country. The act of political and economic suppression, oppression, and domination of the "others" by the powerful in the Nigerian society fits the description, in the case of Esau and Jacob saga, of a "... political history which leaves two neighbouring peoples embittered enemies." $" 62$

\section{The Religious Dimension of the Issue}

Religious schema has always worked for the Northerners in political affairs. Following the smooth fusion and assimilation of the Hausa and Fulani ethnic extraction in the North into a new Hausa-Fulani ethnic group or tribe via the vehicle of Usman dan Fodio's jihad of 1804, the religion of Islam was used as a unifying principle of brotherhood for all Muslim converts. Islamic culture, worldview, and ideology were, therefore, used to put in place a new and vibrant system of socio-political and socio-economic governance administered under sharia law. ${ }^{63}$ No true Muslim, either from the Hausa-Fulani extraction or a convert to Islam from other tribes, separates the sacred from the secular spheres of life. The sacred domain takes precedence and assimilates all others. Aided by the British colonial political legacy, the Muslim Hausa-Fulani group has used this system of governance to its advantage. Consequently, whenever the political and economic agenda of the Muslim "Core North" is perceived to be in jeopardy, they would easily appeal to religion to achieve their ends. Even Attahiru M. Jega, a professor of political science, who himself is a respected devout Muslim, admits that this is the case when he said, "... competitive partisan political activities are ... often infused with excessive religiosity." 64 Most Nigerian politicians, some of whom only pay lip service to their religious profession, in Oluwaseun Afolabi's opinion, use it as an instrument of oppression and deceit. ${ }^{65}$ This, however, is an oblivious way of using religion. Olufemi O. Oluniyi observes,

... religion by its very nature translates into integrity, transparency, and accountability in the public arena and public affairs. Forcing it into any other role is rotten for religion, bad for politics generally, and particularly ugly for governance. ${ }^{66}$

62 Krause, "Tradition," 478.

63 Turaki explains that sharia is the Islamic legal system that regulates the social and religious life of Muslims, and therefore, exerts tremendous social, legal, and political power within Muslim states. See Yusufu Turaki, Tainted Legacy: Islam, Colonialism and Slavery in Northern Nigeria (Virginia: Isaac Publishing, 2010), 45.

64 Attahiru M. Jega, Democracy, Good Governance and Development in Nigeria (Nigeria: Spectrum, 2007), 117.

65 Oluwaseun Olawale Afolabi, "The Role of Religion in Nigerian Politics and its Sustainability for Political Development," Net Journal of Social Sciences 3 (2015): 42.

66 Olufemi Olayinka Oluniyi, The Council of Ulama and Peaceful Co-existence in Nigeria (Nigeria: Frontier, 2006), 95. 
The domineering superior attitude of one-sided religiosity that is insensitive to civility, tolerance, and accommodation is a basic factor for animosity in Nigeria. The perceived status value of Islam by adherents is also a critical crisis factor at this point. The claimed superiority of Islam over other religions and Allah over other gods, and by and large, that of its adherents over other people, does not allow the former to subject themselves under the rule or leadership of a non-Muslim, usually perceived and described derogatorily as a kafir (an infidel) or an arne (an irreligious non-Muslim convert). The principle used by the Muslim Hausa-Fulanis in this connection to maneuver, manipulate, and control the political arena, is to "lie low" where they are in the minority, but to assume full dominance, even forcefully and unjustly so, where they are in the majority. Matthew H. Kukah puts it aptly, in his discourse on the use of religion and the politics of Abuja to achieve the Northern hegemony by the Northern ruling class:

... the northern ruling class ... had to use the tricks that had been tried and tested through time, namely, softening up the opposition through various favours and conciliatory gestures, holding out the hand of friendship, while concealing the hidden agenda of their aims. ${ }^{67}$

This recalls to memory Jacob's opportunistic and manipulative attitude. Equally, it recalls the hostile reaction of the Edomites against Israel on this ground. Suggestively, given the Nigerian political terrain, when aggrieved regions and ethnic groups or tribes discover such Muslim Hausa-Fulani manipulative scheming and their tyrannical attempt to establish the agenda of Northern hegemony, they would naturally react in vengeance as the Edomites reportedly did to Israel (Obad vv. 13-14). Such reactions usually result from provocation. As Matthew Michael points out from his study of angry scenes from the biblical text,

In all cases of designated anger, the anger expressed by the characters was primarily based on some form of provocations. In fact, there are no characters in [the] biblical narrative who are said to be angry without some form of provocations. ${ }^{68}$

Since the experience of 21st Century Nigerian social and political society seems to work against the principle of building a nation where peace and justice reign, restrain is therefore called for at the sight of any reactionary reprisal by any non-Muslim Hausa-Fulani group.

The act or attitude of injustice and unfair treatment and suppression of human rights by government, ethnic group, or by religion can easily spark up

67 Rev. Fr. Matthew Hassan Kukah, Religion, Politics and Power in Northern Nigeria (Nigeria: Spectrum, 1993; repr., 2011), 161.

68 Michael, "Anger Management," 456. 
reaction via hostility and open violence in the face of such glaring imbalances. It seems logical to allow space for such reaction and not quick to condemn; for the oppressed minorities reserve the political, social, moral, human, legal, and constitutional right to respond to persistent acts of injustice and fight to sustain their fundamental human rights enshrined in the constitution. More so, as Michael explains, “... anger negates our humanness, and subconsciously transports the angry person to the dark region of unconscious repressions where the remaining dormant animal self is forcefully brought back to life."69 As stated above, the Edomites who felt their progenitor was unjustly treated through manipulation by Jacob, behaved in this manner toward the Israelites. A similar situation is being expressed, particularly within the Middle Belt region of Nigeria. The ethnic groups or tribes who were dispossessed of their ancestral land and made slaves in their own land, have and will continue to react against the Muslim Hausa-Fulani oppressive domination. Ironically and unfairly so, while they cannot claim any land rights in any part of the country, the Muslim Hausa-Fulanis, aided by the British rule, subordinated them to second class status and to slavery under the Muslim Hausa-Fulanis, giving the latter full land rights in the Middle Belt. This is not only provocative and an abuse of human dignity, but much more, it is oppressive, unfair, unjust, and dehumanising. Worst, the imposition of Muslim Hausa-Fulani rulers on the Middle Belters and their frantic quest to also impose sharia on them consequently, "... has generated political violence and conflict and has caused religious riots between Christians and Muslims."70 This climate becomes obvious because such oppressors are not, in all honest intention, willing to apply the principle of considerateness and peaceful coexistence to society despite the peaceful disposition of the oppressed. Oluniyi correctly points out that it is the observance of this principle by all, regardless of social, cultural, and religious affiliation, that "... yields stability, while its violation ultimately breeds injustice, inequality, domination, oppression, rebellion, and violence."71

\section{The Sociological and Ethnic Dimensions of the Issue}

Jacob Oluwole Odeyemi describes negative ethnicity as a virus that

... has been one of the most definitive causes of social crisis, injustice, inequality and religio-political instability in Nigeria....

69 Michael, "Anger Management," 452. Perceived as a reactionary response (legitimate or illegitimate), to discomforting external stimuli, Michael is absolutely right in his description of its effects when he said, "... anger is particularly responsible for war and violence, the destruction of lives and properties, animosity, rivalry, crimes and other social vices."

70 Turaki, Tainted Legacy, 170.

71 Oluniyi, Council, 101. 
[that has acted] as a major obstacle to the overall politico-economic development of the country. ${ }^{72}$

Yaw Adu-Gwamfi also asserts that "Ethnicity is central to Africans." ${ }^{.73}$ Ethnicity is a major leading identification mark in many African societies such as Nigeria. By divine economy and design, ethnic distinctiveness should enhance a cordial relationship for a cohesive society rather than cause division and strife in the human family. ${ }^{74}$ When ethnicity is allowed to come to prominence in human relationships, it cracks and tears rather than blends and builds relationships in the Nigerian society. The feeling of superiority of one ethnic group over the other is only a human creation that ought not to determine the methodology and direction on how relationships in society are to operate. The act of oppression, subjugation, unequal treatment, superiority-inferiority attitude, and so on by any ethnic group, therefore, goes without saying, will grossly affect relationships. This explains the sour relationship that has existed among the Muslim Hausa-Fulani extraction and other ethnic groups or tribes, particularly in the North in post-independent Nigeria. In defence of the reaction of the Christian students to the provocation of the Muslim students that led to the Kafanchan crisis of 6 March, 1987, Fr. Kukah posits,

It is argued here that these developments represent a flash point in the socio-political and historical processes in Southern Zaria in relation to the ruling class in the region.... Coming against the background of unequal relations that have been characterised by so many years of degradation and humiliation. ${ }^{75}$

On a wider circle, Agang agrees in the assertion that, "Post-independence regional interests created deep socioeconomic and socio-political crises in Nigeria ... [as] each sought ... to bend the federal government to dance to its tune" 76 regardless of the interests of the other regions. Even at the regional level, socio-ethnic discrimination and rivalry are extant as the indigenous people of these regions are not all of the same tribal stalk nor are they of the same religious faith.

72 Jacob Oluwole Odeyemi, "A Political History of Nigeria and the Crisis of Ethnicity in Nation-Building," IJDS 3 (2014): 87-95, doi: 10.11634 /216817831403459.

73 Yaw Adu-Gwamfi, "Prevention of Civil War in Joshua 22: Guidelines for African Ethnic Groups," OTE 26 (2013): 247.

74 For example, Ruth's ethnic identity transformation, first, as a Moabite, second, as an Israelite, then lastly, as none of these appears a good model for an existing cordial relationship within the fragile socio-political and socio-religious terrain of modern Nigeria. See further discussion on this model in Neil Glover, "Your People, My People: An Exploration of Ethnicity in Ruth," JSOT 33 (2009): 293-313.

75 Kukah, Religion, 185.

76 Agang, Impact, 13. 
Relationships in modern Nigeria are that of suspicion and distrust, especially for the Muslim Hausa-Fulani ethnic extraction, in the national scheme of things. Even politicians from other parts of the country but the North who are hungry for political power to satisfy their self-aggrandisement, relate with this class of citizens only on a peripheral political level, not on the principle of true brotherhood and nationhood as citizens. Such relationships of suspicion and distrust are largely responsible for the political and economic backwardness of the country. All the political gimmicks that Nigerian politicians fly around about the growth of democracy in Nigeria and its economic developments can hardly be substantiated on the basis of true decimal measurement. Instead of settling for political, religious, and ethno-tribal violence, Adu-Gwamfi recommends that the facts of all kinds of allegations are to be carefully investigated; meaningful dialogue is to be engaged by people of unquestioned moral integrity to mediate between aggrieved parties; and governments must make conscious effort at implementing whatever reasonable and just recommendations are arrived at from such dialogue. ${ }^{77}$ Even then, as long as the perceived offending brother refuses to acknowledge his faults and to seek peaceful recognition, and consequently, where the aggrieved parties are unwilling to apply the Christological and Pauline ethic of repaying evil with good (see Matt 5:43-48; Phil 2:5-8; Prov 25:20-22) and as being the keeper of one's brother (Gen 4:9), members of the Nigerian family will continue to "... stifle their natural affections and commit violent acts against each other."78 This way, the latter will have been acting vindictively and vengefully like the Obadian propaganda instead of seeking meaningful ways to resolve the ancient conflict (Obad vv. 18-22).

\section{CONCLUSION}

The prolonged unabated abnormal relationship situation presented in this work is not without its benefiting sponsors. Jega explains,

Those who have profited from exploring negative passions and igniting the embers of ethno-religious conflagration in the past are at it again, evidently in full swing, mobilising negative ethnicity, religious bigotry and intolerance, whipping up sentiments and pitching one ethno-religious group against another. ${ }^{79}$

According to Turaki, internal conflict has continued in Nigeria since independence. While making a case for a socio-politically knitted modern Nigeria that is to be founded on the principle of justice, freedom, equity, and the equality of all the Nigerian people, he submits that this can be achieved only when the historical evils that have shaped the country are justly addressed.

77 Adu-Gwamfi, "Prevention of Civil War," 259-260.

78 Block, Obadiah, 108.

79 Jega, Democracy, 117. 
"To find solutions to the problems facing Nigeria, we must reach down deep to the nation's social foundations." 80 Also, while rooting his consolatory supposition from the Obadian text, Adu-Gyamfi asserts,

Victims of ethnic hatred in Africa should console themselves with the fact that God will administer justice that would see to the punishment of those who take advantage of their condition... ${ }^{81}$

But apparently, this appears more a mirage than reality for the Nigerian experience. As long as the exhibition of the attitude of superiority-inferiority, political domination, regional socio-religious and political manoeuvre and manipulation exits in the Nigerian society, the dream of a truly national unity will only be a mirage. Also, as long as Nigerians fail to honestly and frankly tell one another the truth at different regional, national, and conflict and peace resolution fora, generational ethno-regional tension, conflict, and hostility will continue to widen the social gap of relationships and thwart the nation's political progress. Peaceful coexistence and a cohesive society cannot be achieved in the absence of social accommodation and political and religious tolerance. Creating ethical ${ }^{82}$ space for ethno-religious humility, equity and fairness, and a harmonious peaceful co-existence in the land is a defusing antidote to regional and national conflict. Only the mind-set of thinking, speaking, and acting for the good of one's brother and neighbour can achieve the dream of Nigeria's founding fathers of a one united Nigeria.

When human beings are opened to learning lessons from divine moral laws, then the basic components of loving one's neighbour as one's self and of expressing mercy and compassion toward other people will serve as key guiding principles for cordial and meaningful human relationships. Also, the honest attitude of admitting one's wrong perception and or treatment of other people on the one hand, and that of forgiving an offender on the other hand, are essential. Only on this ground could we affirmatively respond to the nagging moral question whether ethno-regional conflict is to continue or that brothers in conflict are to sheath the sword, forgive and tolerate one another, and defend the just course of a brother for society's and humanity's common good.

The issue, however, becomes complex where the perpetrating and offending brother becomes arrogant, adamant, nonchalant, and unremorseful

80 Turaki, Tainted Legacy, 167.

81 Yaw Adu-Gyamfi, "God's Wrath and Judgment on Ethnic Hatred and Hope for Victims of Ethnic Hatred in Obadiah: Implications for Africa," OTE 28 (2015): 11.

82 The ethical or moral lessons derivable from Seidl's discussion of using the principle of reconciliation for conflict resolution from the Abraham-Lot, Esau-Jacob, and Joseph-his brothers' narrative texts in the Pentateuch is a helpful tool for the Nigerian situation. Theodor Seidl, "Conflict and Conflict Resolution: Inner Controversies and Tensions as Places of Israel's Self-Conception in the Patriarchal Traditions of Genesis," OTE 26 (2013): 840-863. 
for the evil done to his offended brother. Worse, it hurts the more when he rather continues to superimpose his assumed superiority de facto over the other instead of seeking to achieve a cohesive relationship. Here, then, the honest, just, and fair application of the instruments of good democratic governance by governing authorities becomes an inevitable tool to ensure and enhance a cohesive peaceful Nigerian society.

\section{BIBLIOGRAPHY}

Abubakar, Sa'ad. "The Northern Provinces Under Colonial Rule: 1900-1959.” Pages 447-481 in Groundwork of Nigerian History. Edited by Obaro Ikime. Nigeria: Heinemann, 1980. Repr., 2004.

Adu-Gwamfi, Yaw. "Prevention of Civil War in Joshua 22: Guidelines for African Ethnic Groups." OTE 26/2 (2013): 247-262. . "God's Wrath and Judgment on Ethnic Hatred and Hope for Victims of Ethnic Hatred in Obadiah: Implications for Africa." OTE 28/1 (2015): 11-30.

Afolabi, Oluwaseun Olawale. "The Role of Religion in Nigerian Politics and its Sustainability for Political Development." NJSS 3/2 (2015): 42-49.

Agang, Sunday Bobai. The Impact of Ethnic, Political, and Religious Violence on Northern Nigeria, and a Theological Reflection on Its Healing. Cumbria: Langham Monographs, 2011.

Allen, Leslie C. The Books of Joel, Obadiah, Jonah and Micah. NICOT. Michigan: Eerdmans, 1976.

Anderson, Bradford A. "Poetic Justice in Obadiah." JSOT 35/2 (2010): 247-255. Armerding, Carl E. “Obadiah.” Pages 333-357 in vol. 7 of The Expositor's Bible Commentary. Edited by Frank E. Gaebelein. Michigan: Zondervan, 1985.

Assis, Elie. "Structure, Redaction and Significance in the Prophecy of Obadiah." JSOT 39/2 (2014): 209-221.

Baker, David W. Joel, Obadiah, Malachi. NIVAC. Michigan: Zondervan, 2006.

Baker, Walter L. "Obadiah.” Pages 1453-1459 in The Bible Knowledge Commentary: Old Testament. Edited by John F. Walvoord and Roy B. Zuck. Wheaton: SP Publications, 1987 [repr.1985].

Ben Zvi, Ehud. "De-Historicizing and Historicizing Tendencies in the Twelve Prophetic Books: A Case Study of the Heuristic Value of a Historically Anchored Systematic Approach to the Corpus of Prophetic Literature." Pages 37-56 in Israel's Prophets and Israel's Past: Essays on the Relationship of Prophetic Texts and Israelite History in Honor of John H. Hayes. Edited by Brad E. Kelle and Megan Bishop Moore. LHBOTS 446. New York: T \& T Clark, 2006.

Block, Daniel Isaac. Obadiah: The Kingship Belongs to YHWH. Michigan: Zondervan, 2013.

Botha, Phil J. "Social Values in the Book of Obadiah." OTE 16/3 (2003): 581-597.

Bridge, Edward J. "Polite Israel and Impolite Edom: Israel's Request to Travel through Edom in Numbers 20.14-21." JSOT 35/1 (2010): 77-88. . "The 'Slave' Is the 'Master': Jacob's Servile Language to Esau in Genesis 33.1-17." JSOT 38/3 (2014): 263-278.

Brueggemann, Walter. Genesis. IBC. Georgia: John Knox Press, 1982. 
Bullock, Clarence Hassell. Introduction to the Old Testament Prophetic Books. Updated ed. Illinois: Moody, 2007.

Dicou, Bert. Edom, Israel's Brother and Antagonist: The Role of Edom in Biblical Prophecy and Story. Sheffield: JSOT Press, 1994.

Eidevall, Göran. Sacrificial Rhetoric in the Prophetic Literature of the Hebrew Bible. Lewiston: Edwin Mellen, 2012.

Gasque, W. Ward. “Obadiah.” Pages 914-915 in The International Bible Commentary. Edited by Frederick F. Bruce. New ed. Michigan: Marshall Morgan \& Scott, 1986.

Glover, Neil. "Your People, My People: An Exploration of Ethnicity in Ruth." JSOT 33/3 (2009): 293-313.

Hays, J. Daniel. The Message of the Prophets: A Survey of the Prophetic and the Apocalyptic Books of the Old Testament. Edited by Tremper Longman III. Michigan: Zondervan, 2010.

Jega, Attahiru Muhammadu. Democracy, Good Governance and Development in Nigeria. Nigeria: Spectrum, 2007.

Jenson, Philip Peter. Obadiah, Jonah, Micah: A Theological Commentary. London: T \& T Clark, 2008.

Kalejaiye, Peter O. and Nurudeen Alliyu. "Ethnic Politics and Social Conflicts: Factors in Nigeria's Underdevelopment." JISR 6/27 (2013): 252-262.

Krause, Joachim J. "Tradition, History, and Our Story: Some Observations on Jacob and Esau in the Books of Obadiah and Malachi." JSOT 32/4 (2008): 475-486.

Kukah, Rev. Fr. Matthew Hassan. Religion, Politics and Power in Northern Nigeria. Nigeria: Spectrum, 1993. Repr., 2011.

Limburg, James. Hosea - Micah. IBC. Georgia: John Knox Press, 1988.

McComiskey, Thomas Edward. "Introduction." Pages xi-xii in Obadiah, Jonah, Micah, and Habakkuk. Edited by Thomas Edward McComiskey Vol. 2 of The Minor Prophets: An Exegetical and Expository Commentary. Edited by Thomas Edward McComiskey; Michigan: Baker Academic, 1993. Repr., 2006.

Michael, Matthew (Rabbi Mikhail). "Anger Management and Biblical Characters: A Study of 'Angry Exchange' among Characters of Hebrew Narrative." OTE 28/2 (2015): 451-480.

Nicolson, Ian F. The Administration of Nigeria, 1900-1960. Oxford: Clarendon, 1969.

Niehaus, Jeffrey J. "Obadiah.” Pages 495-541 in Obadiah, Jonah, Micah, and Habakkuk. Edited by Thomas Edward McComiskey. Vol. 2 of The Minor Prophets: An Exegetical and Expository Commentary. Edited by Thomas Edward McComiskey. Michigan: Baker Academic, 2006.

Nyirimana, Eraste. "Patrimonialism in the Causes of the Division of the Kingdom in Israel: A Reading of the Division Narrative from the Perspective of the Rwandan Context of Social Conflict." OTE 24/3 (2011): 708-730.

Odeyemi, Jacob Oluwole. "A Political History of Nigeria and the Crisis of Ethnicity in Nation-Building." IJDS 3/1 (2014): 87-95, doi: 10.11634 1216817831403459.

Olanisebe, Samson O. "The Justice of God in his Anger: A Narrative Analysis of Isaiah 5:1-7 and its Implications for Socio-Economic and Security Challenges in Nigeria." OTE 28/2 (2015): 481-496. 
Oluniyi, Olufemi Olayinka. The Council of Ulama and Peaceful Co-existence in Nigeria. Nigeria: Frontier, 2006.

Osaghae, Eghosa E. Nigeria Since Independence: Crippled Giant. Indiana: Indiana University Press, 1998.

Payne, David F. “Genesis Chapters 12-50.” Pages 123-148 in The International Bible Commentary. Edited by Frederick F. Bruce. New ed. Michigan: Marshall Morgan Scott, 1986.

Potgieter, Henk (J. H.). “A Poetic Analysis of Obadiah.” OTE 16/3 (2003): 653-667.

Premnath, Joel D. N. "Obadiah." Page 145 in The Old Testament and Ethics. Edited by Joel B. Green and Jacqueline E. Lapsley. Michigan: Baker Academic, 2013.

Ross, Allen P. "Genesis.” Pages 15-101 in The Bible Knowledge Commentary: Old Testament. Edited by John F. Walvoord and Roy B. Zuck. Wheaton: SP Publications, 1985. Repr., 1987.

Sailhamer, John H. "Genesis." Pages 1-284 in vol. 2 of The Expositor's Bible Commentary. Edited by Frank E. Gaebelein. Michigan: Zondervan, 1990.

Schipper, Jeremy. Parables and Conflicts in the Hebrew Bible. Cambridge: Cambridge University Press, 2009.

Seidl, Theodor. "Conflict and Conflict Resolution: Inner Controversies and Tensions as Places of Israel's Self-Conception in the Patriarchal Traditions of Genesis." OTE 26/3 (2013): 840-863.

Stuart, Douglas. Hosea - Jonah. WBC 31. Texas: Word, 1987.

Tamuno, Tekena N. "British Colonial Administration in Nigeria in the Twentieth Century." Pages 393-409 in Groundwork of Nigerian History. Edited by Obaro Ikime. Nigeria: Heinemann, 1980. Repr., 2004.

. The Evolution of the Nigerian State: The Southern Phase, 1898-1914. London: Longman, 1972.

Tebes, Juan Manuel. "The Edomite Involvement in the Destruction of the First Temple: A Case of Stab-in-the Back Tradition.” JSOT 36/2 (2011): 219-255.

Turaki, Yusufu. The British Colonial Legacy in Northern Nigeria: A Social Ethical Analysis of the Colonial and Post-Colonial Society and Politics in Nigeria. Nigeria: Challenge, 1993.

. Tainted Legacy: Islam, Colonialism and Slavery in Northern Nigeria.

Virginia: Isaac Publishing, 2010.

Ukiwo, Ukoha. "Politics, Ethno-Religious Conflicts and Democratic Consolidation in Nigeria." JMAS 41/1 (2003): 115-138, doi: 10.1017/S0022278X02004172.

Wenham, Gordon J. Genesis 16-50. WBC 2. Texas: Word, 1994.

Rev. Dr. Joel Kamsen Tihitshak Biwul is Associate Professor of Old Testament and Pastoral Theology at ECWA Theological Seminary, Jos, Nigeria where he serves as Deputy Provost and Acting Dean for Academic Affairs. He is a Research Fellow, Old and New Testament, Faculty of Theology, University of Stellenbosch, South Africa. Email: biwuljetscholar@gmail.com. 